УДК: 635.655:631.527 DOI 10.31210/visnyk2018.03.12

(C) 2018

Білявська Л. Г., кандидат сільськогосподарських наук,

Рибальченко А. М., здобувач

(науковий керівник - кандидат сільськогосподарських наук Л. Г. Білявська)

Полтавська державна аграрна академія

\title{
ФОРМУВАННЯ НАСІННСВОЇ ПРОДУКТИВНОСТІ У КОЛЕКЦІЙНИХ ЗРАЗКІВ СОЇ В УМОВАХ ЛІСОСТЕПУ УКРАЇНИ
}

\section{Рецензент - доктор сільськогосподарських наук, професор Писаренко П.В.}

В статті наведені результати досліджень щзодо формування насіннєвої продуктивності колекційних зразків сої протягом 2013-2015 рр. Виділено цінні зразки для подальшої селекційної роботи за такими важливими ознаками, як маса 1000 насінин та відповідно кількість насіння з рослини та маса насіння 3 рослини. Встановили, щуо серед зразків ультраскоростиглої групи за ознакою маса 1000 насінин суттєво перевищували сорт-стандарт Аннушку такі зразки, як OAC Vision (167,332), LF-8 (155,00 2), Gaillard (162,33 г), Злата (150,00 г). В скоростиглій групі такі сорти, як Алмаз (183,67 г), Устя (179,33 г), Кивін (184,67 2), Адамос (164,67 г), Вільшанка (165,00 г), Мрія (168,00 г), Юг-40 (165,67 г), Фортуна (168,00 г), Поема (171,00 г), Хвиля (173,00 г), Артеміда (165,00 2) були кращуими за сорт-стандарт Васильківська. Кращими за сорт-стандарт Чернівецьку-8 у середньостиглій групі стиглості були Подолянка (178,33 2), Маша (176,67 г), Фарватер (176,33 г), Славія (176,00 г), Ельдорадо (179,33 г), Іванка (175,33 г).

Стабільним за коефіцієнтом регресії $\left(b_{i}\right)$ з високою масою 1000 насінин виділено зразок Алмаз

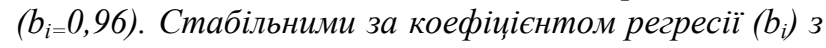
високою масою насіння з рослини виділені зразки Ки-

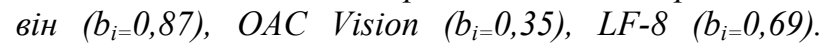
Стабільним за коефіцієнтом регресії $\left(b_{i}\right)$ з високою кількістю насіння з рослини виділено зразок Кивін $\left(b_{i=} 0,97\right)$.

Ключові слова: соя, зразок, колекційний матеріал, маса 1000 насінин, насіннева продуктивність.

Постановка проблеми. Сою називають культурою XXI століття. Культура потужно входить у світове землеробство й економіку, закріплює позиції в структурі посівів [1]. Незважаючи не значне розширення площ під соєю, урожайність iї в Україні залишається низькою. Для нарощення виробництва сої першочерговим завданням $€$ цілеспрямована робота над створенням і впровадженням у виробництво високопродуктивних i високоякісних сортів, пристосованих до конкретних умов вирощування $[7,12]$.

Реалізація потенціалу продуктивності певного сорту сої тісно пов'язана 3 його адаптивними властивостями - пластичністю та стабільністю. Тому для переважно посушливих умов України потрібні сорти з високою або середньою пластичністю та високою стабільністю головних кількісних ознак - компонентів урожайності [2].

Аналіз останніх досліджень і публікацій, у яких започатковано розв'язання проблеми. Формування врожаю зернобобових, зокрема i сої, $є$ надзвичайно складним процесом, значно складнішим, ніж у інших культур. Це пов'язано зі слабкою здатністю регулювання числа плодоносних стебел, послідовною та тривалою диференціацією генеративних органів та, особливо, зі значною залежністю їх розвитку від зовнішніх умов $[14,15]$.

Кожному сорту властиві певні прояви і взаємозв'язок елементів структури насіннєвої продуктивності рослин, ступінь мінливості і наявність найбільш характерних з них, які у межах сорту найменше змінюються [10].

Світові генетичні ресурси відіграють першорядну роль для створення нових сортів. Успіх селекції залежить від правильного підбору вихідного матеріалу. Не всі зразки світової колекції придатні для безпосереднього використання в селекції через низьку продуктивність, екологічну непристосованість, біологічної несумісність. Залучення такого вихідного матеріалу в селекційний процес значно подовжує його, що не відповідає сучасним вимогам [5].

Урожайність сорту визначається перш за все його продуктивністю та кількістю рослин на одиницю площі. Вивченню вихідного матеріалу за рівнем урожайності та продуктивності присвячено багато робот вітчизняних та закордонних вчених, де показано різноманіття вихідного матеріалу за цими ознаками та вплив на їх формування кліматичних умов $[7,17]$.

Продуктивність рослини знаходиться у тісному кореляційному зв'язку з кількістю бобів та насінин на рослині, в меншій мірі - 3 кількістю бобів у вузлі і насінин у бобі. Зв'язок продуктивності 3 тривалістю періоду вегетації спостеріга- 
ється лише в сприятливі роки [8]. Одним із важливих елементів продуктивності рослин сої, що впливає на формування потенційної та фактичної врожайності, є «маса 1000 насінин». Тому вивчення прояву цієї ознаки, мінливості та зв'язків 3 іншими ознаками у гібридних поколіннях має важливе практичне значення для визначення пріоритетних параметрів добору при селекції нового покоління високоврожайних біотипів для конкретних агрокліматичних зон вирощування [11].

Успіх селекційної роботи з будь-якою сільськогосподарською культурою більше залежить від правильно відібраного вихідного матеріалу. Наявність донорів і джерел цінних господарських ознак дозволяє селекціонеру цілеспрямовано конструювати нові генотипи шляхом використання певних генів і їх блоків у програмах гібридизаціі. При цьому дуже важливо при створенні нового вихідного матеріалу залучати більш віддалені форми - носії цінних генів, що дає можливість суттєво розширити генетичну базу селекційного матеріалу [13].

Тому, оцінка селекційного матеріалу за комплексом господарсько-цінних ознак має важливе значення при створенні нових високопродуктивних сортів 3 адаптивним потенціалом та покращеною якістю насіння [9].

Мета досліджень. Метою наших досліджень було виявити зразки 3 високим рівнем формування насіннєвої продуктивності, визначити рівень мінливості господарсько цінних ознак у сортозразків сої в умовах Лісостепу України та виділити цінні зразки зі стабільним проявом високої насіннєвої продуктивності для подальшої селекційної роботи.

Матеріали і методи досліджень. Польові дослідження виконані протягом 2013-2015 рр. на дослідному полі Полтавської державної аграрної академіі, що за зональним розподілом належить до центральної зони Лісостепу України. Об'єктом дослідження були 145 колекційних зразків сої вітчизняної та зарубіжної селекції.

Метеорологічні умови періоду вегетації сої у роки досліджень відрізнялися. Гідротермічний коефіцієнт вегетаційного періоду сої за роки досліджень 2013-2015 pp. становив відповідно 1,$39 ; 1,34 ; 0,84$ (рис. 1).

Середній багаторічний показник ГТК для ярих культур в зоні Лісостепу становить 1,0.

Найменш сприятливими були погодні умови вегетаційного періоду 2015 року. У липні, серпні, вересні 2015 року погодні умови були надзвичайно посушливими (липень ГТК $=0,66$; серпень $-\Gamma T K=0,13$; вересень $-\Gamma T K=0,2)$. Лише у травні $(\Gamma \mathrm{TK}=1,33)$ та червні $(\Gamma \mathrm{TK}=1,98)$ погодні умови характеризувались як оптимальні. Погодні умови 2014 року в травні $(Г Т К=0,98)$, липні $(\Gamma T К=0,67)$ та серпні $(\Gamma T К=0,54)$ характеризувались як досить посушливі. Умови червня та вересня за рівнем ГТК характеризувались, як надмірно зволожені (червень $-\Gamma \mathrm{TK}=2,42$; вересень $-\Gamma \mathrm{TK}=2,10)$.

Відмінність погодних умов 2013 року полягала у надмірному зволоженні у вересні місяці $(Г Т К=2,89)$, інші місяці були більш сприятливими для росту і розвитку рослин (травень - ГТК $=0,90 ;$ червень $-\Gamma \mathrm{TK}=1,42$; липень $-\Gamma \mathrm{TK}=$ 1,03; серпень $-\Gamma T К=0,70)$ (рис. 2).

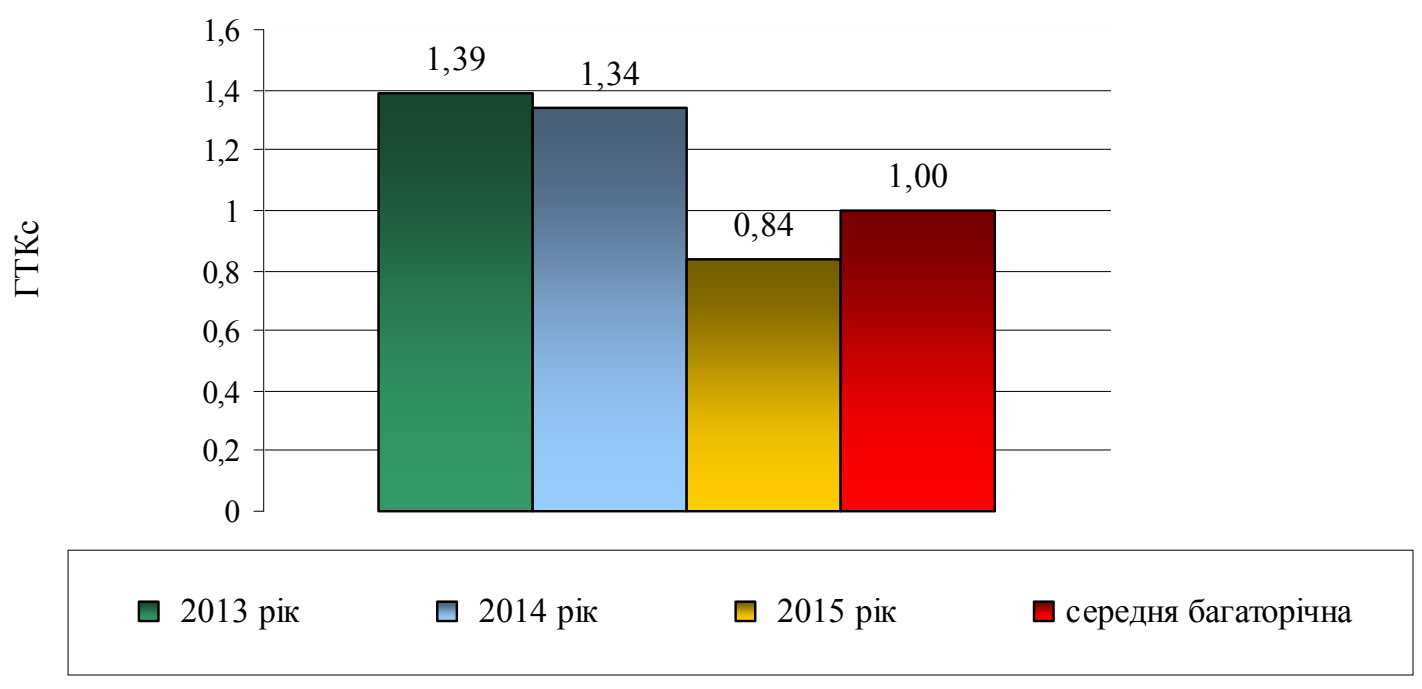

Рис. 1. Гідротермічний коефіцієнт за періоди вегетації сої у 2013-2015 pp. порівняно із середньюю багаторічною нормою 


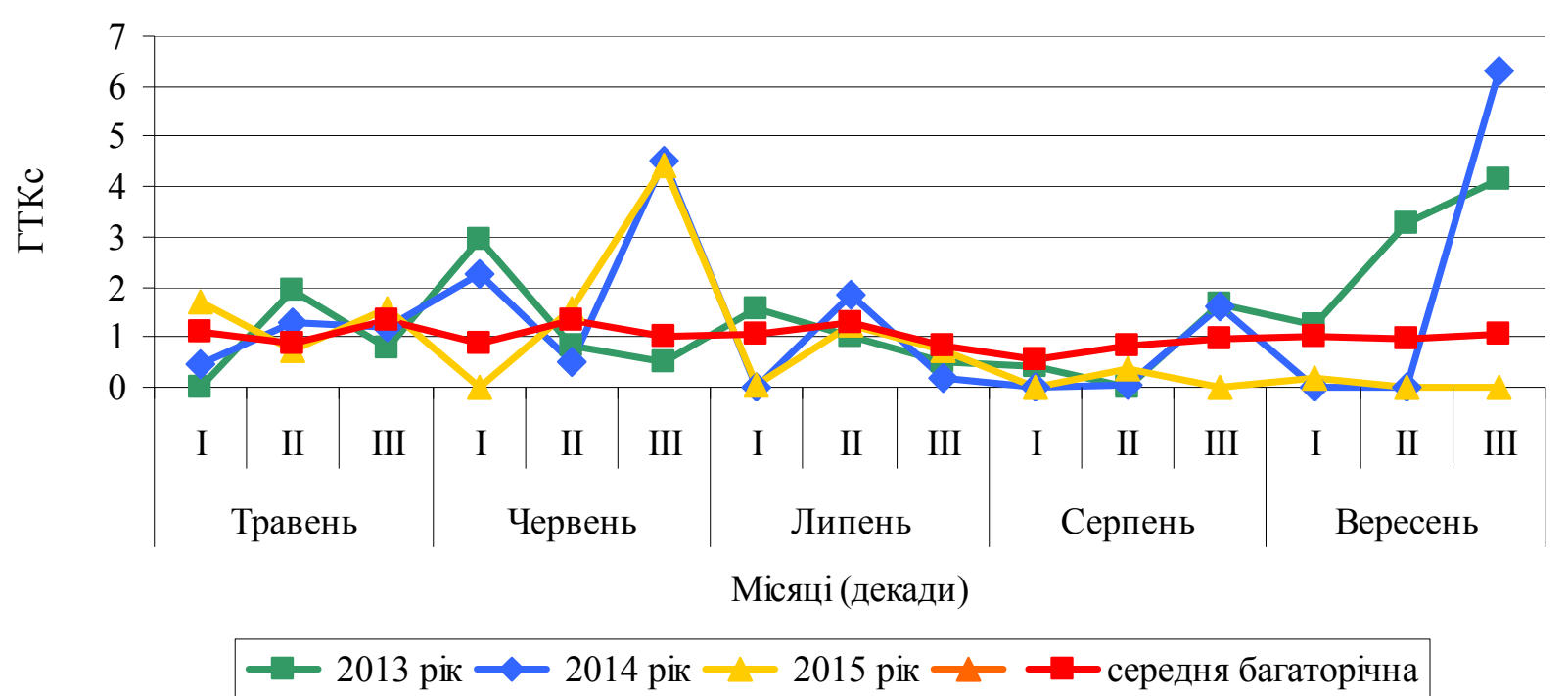

Рис. 2. Гідротермічний коефіцієнт розрахований подекадно за періоди вегетації сої y 2013-2015 рр. порівняно із середньою багаторічною нормою

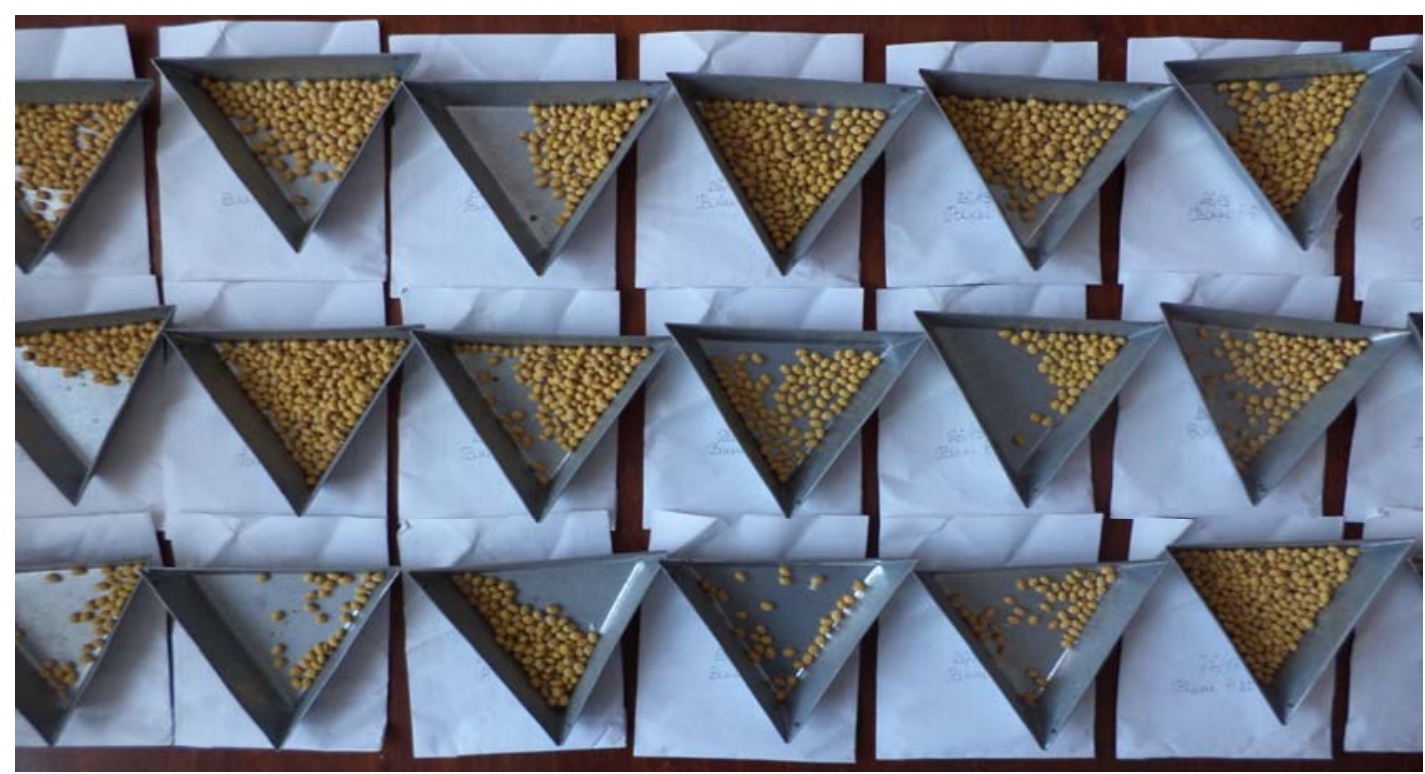

Рис. 3. Визначення кількості насіння з рослин у колекційного зразка сої

Агротехніка вирощування колекційних зразків - загальноприйнята для зони. Продуктивність рослин кожного зразка визначали методом відбору проб (по 25 рослин 3 ділянки) та усередненням результатів. Проводили фенологічні спостереження 3 наступним розподілом зразків за групами стиглості. Збирали урожай вручну. Також визначали біометричні параметри рослин (рис. 3).

Загалом зразки сої за господарськими ознаками, зокрема кількістю насіння з рослини, масою насіння 3 однієї рослини, масою 1000 насінин вивчали згідно загальноприйнятих методик [6, $13,17]$.
Результати досліджень. Показник маси 1000 насінин в середньому за 2013-2015 рр. у колекційних зразків знаходився в межах 119,33-191,33 г.

За масою 1000 насінин досліджувані зразки розподілено на три групи. Це групи із низькою масою 1000 насінин (71-130 г), середньою (131190 г) та високою (191-250 г). Високою масою 1000 насінин характеризувавсь лише 1 зразок сої (Нејіао 87-94-3) з Китаю. 3 середньою масою 1000 насінин виділили 136 зразків. Низьку масу 1000 відмічено у 8 зразків (Білявка, Юг-30, Сузір'я, Kari Kachi, Nattawa, Dunajka, Харківська-80, Sacura) (табл. 1). 
СІЛЬСЬКЕ ГОСПОДАРСТВО. РОСЛИННИЦТВО

\section{1. Розподіл колекції сої за масою 1000 насінин, г (середнє за 2013-2015 рр.)}

\begin{tabular}{|c|c|c|c|}
\hline \multirow{2}{*}{$\begin{array}{l}\text { Маса } 1000 \\
\text { насінин, г }\end{array}$} & \multicolumn{2}{|c|}{ Кількість від загальної маси } & \multirow{2}{*}{ Назва зразка } \\
\hline & штук & $\%$ & \\
\hline $\begin{array}{c}\text { низька } \\
(71-130)\end{array}$ & 8 & 5,5 & $\begin{array}{c}\text { Білявка, Юг-30, Сузір'я, } \\
\text { Kari Kachi, Nattawa, Dunajka, } \\
\text { Харківська-80, Sacura }\end{array}$ \\
\hline $\begin{array}{c}\text { середня } \\
(131-190)\end{array}$ & 136 & 93,7 & $\begin{array}{l}\text { Алмаз, Кивін, Подолянка, Славія, } \\
\text { Ельдорадо, Іванка, Фарватер та ін. }\end{array}$ \\
\hline $\begin{array}{c}\text { висока } \\
\text { (191-250). }\end{array}$ & 1 & 0,8 & Hejiao 87-94-3 \\
\hline Усього: & 145 & 100 & \\
\hline
\end{tabular}

2. Кращі зразки колекції сої за ознакою маса 1000 насінин, г (середнє 2013-2015 рр.)

\begin{tabular}{|c|c|c|c|c|c|c|c|c|}
\hline $\begin{array}{l}\text { № } \\
\Pi / \Pi\end{array}$ & $\begin{array}{l}\text { Назва } \\
\text { зразка }\end{array}$ & $\begin{array}{c}\text { Номер } \\
\text { національного } \\
\text { каталогу }\end{array}$ & 2013 & 2014 & 2015 & $\bar{X} \pm s_{x}$ & $\mathrm{~V} \pm \mathrm{Sv}, \%$ & $b_{i}$ \\
\hline \multicolumn{9}{|c|}{ Ультраскоростиглі (менше 90-100 діб) } \\
\hline 1. & Аннушка-st & UD0201943 & 159 & 148 & 141 & $149,33 \pm 5,24$ & $6,08 \pm 2,48$ & 1,63 \\
\hline 2. & OAC Vision & UD0201929 & 175 & 169 & 158 & $167,33 \pm 4,98$ & $5,15 \pm 2,10$ & 2,10 \\
\hline 3. & LF-8 & UD0202379 & 169 & 152 & 144 & $155,00 \pm 7,37$ & $8,24 \pm 3,36$ & 2,05 \\
\hline 4. & Gaillard & UD0202360 & 151 & 162 & 174 & $162,33 \pm 6,64$ & $7,09 \pm 2,89$ & $-2,46$ \\
\hline 5. & Злата & UD0202426 & 155 & 142 & 153 & $150,00 \pm 4,04$ & $4,67 \pm 1,91$ & $-1,29$ \\
\hline \multicolumn{9}{|c|}{ Скоростиглі (101-120 діб) } \\
\hline 1. & Васильківська-st & UD0202340 & 167 & 172 & 151 & $163,33 \pm 6,33$ & $6,72 \pm 2,74$ & 3,29 \\
\hline 2. & Алмаз & UD0202309 & 192 & 181 & 178 & $183,67 \pm 4,26$ & $4,01 \pm 1,64$ & 0,96 \\
\hline 3. & Устя & UD0200773 & 171 & 180 & 187 & $179,33 \pm 4,63$ & $4,47 \pm 1,83$ & $-1,54$ \\
\hline 4. & КиВін & UD0201952 & 193 & 185 & 176 & $184,67 \pm 4,91$ & $4,61 \pm 1,88$ & 1,84 \\
\hline 5. & Адамос & UD0202628 & 168 & 173 & 153 & $164,67 \pm 6,01$ & $6,32 \pm 2,58$ & 3,12 \\
\hline 6. & Вільшанка & UD0202562 & 166 & 177 & 152 & $165,00 \pm 7,23$ & $7,59 \pm 3,10$ & 3,70 \\
\hline 7. & Мрія & UD0201974 & 159 & 167 & 178 & $168,00 \pm 5,51$ & $5,68 \pm 2,32$ & $-2,17$ \\
\hline 8. & Юг-40 & UD0200203 & 169 & 173 & 155 & $165,67 \pm 5,46$ & $5,71 \pm 2,33$ & 2,83 \\
\hline 9. & Фортуна & UD0202308 & 168 & 181 & 155 & $168,00 \pm 7,51$ & $7,74 \pm 3,16$ & 3,79 \\
\hline 10. & Поема & UD0202304 & 172 & 178 & 163 & $171,00 \pm 4,36$ & $4,42 \pm 1,80$ & 2,25 \\
\hline 11. & Хвиля & UD0202466 & 187 & 174 & 158 & $173,00 \pm 8,39$ & $8,40 \pm 3,43$ & 3,21 \\
\hline 12. & Артеміда & UD0200978 & 165 & 178 & 152 & $165,00 \pm 7,51$ & $7,88 \pm 3,22$ & 3,79 \\
\hline \multicolumn{9}{|c|}{ Середньостиглі (121-140 діб) } \\
\hline 1. & Чернівецька-8-st & UD0200285 & 162 & 178 & 182 & $174,00 \pm 6,11$ & $6,08 \pm 2,48$ & $-1,34$ \\
\hline 2. & Подолянка & UD0200615 & 188 & 179 & 168 & $178,33 \pm 5,78$ & $5,62 \pm 2,29$ & 2,21 \\
\hline 3. & Маша & UD0201933 & 178 & 184 & 168 & $176,67 \pm 4,67$ & $4,58 \pm 1,87$ & 2,41 \\
\hline 4. & Фарватер & UD0202311 & 177 & 186 & 166 & $176,33 \pm 5,78$ & $5,68 \pm 2,32$ & 2,96 \\
\hline 5. & Славія & UD0202451 & 178 & 186 & 164 & $176,00 \pm 6,43$ & $6,33 \pm 2,58$ & 3,33 \\
\hline 6. & Ельдорадо & UD0202315 & 181 & 185 & 172 & $179,33 \pm 3,84$ & $3,71 \pm 1,52$ & 2,00 \\
\hline 7. & Іванка & UD0200238 & 177 & 182 & 167 & $175,33 \pm 4,41$ & $4,36 \pm 1,78$ & 2,29 \\
\hline
\end{tabular}

Результати аналізу маси 1000 насінин свідчать про здатність більшої кількості досліджених зразків формувати середню массу. Так, в середньому за три роки в ультраскоростиглій групі кращими за сорт-стандарт Аннушку виділені ОАС Vision (167,33г), LF-8 $(155,00 \quad$ г), Gaillard $(162,33$ г), Злата $(150,00$ г). В скоростиглій групі такі сорти, як Алмаз $(183,67$ г), Устя $(179,33$ г),
Кивін (184,67 г), Адамос (164,67 г ), Вільшанка (165,00 г), Мрія (168,00 г), Юг-40 (165,67 г), Фортуна (168,00 г), Поема (171,00 г), Хвиля $(173,00$ г), Артеміда $(165,00$ г) були кращими за сорт-стандарт Васильківська. Кращими за сортстандарт Чернівецьку-8 у середньостиглій групі стиглості були Подолянка (178,33 г), Маша (176,67 г), Фарватер (176,33 г), Славія (176,00 г), 


\section{СІЛЬСЬКЕ ГОСПОДАРСТВО. РОСЛИННИЦТВО}

Ельдорадо (179,33 г), Іванка (175,33 г) (табл. 2).

Майже всі зразки за ознакою маса 1000 насінин слабомінливі (коефіцієнт варіації $\mathrm{V}$ менший за 10\%). Серед ультраскоростиглих зразків за коефіцієнтом регресії $\left(b_{i}\right)$ не виявлено стабільних. Більшість цих зразків показали себе як інтенсивні $\left(b_{i}>1\right)$, тобто при покращенні умов вирощування давали кращий результат. Серед скоростиглих стабільними за ознакою виявились зразки Armour, Алмаз, Лика, Краса Поділля, Сузір'я, Nattawa, Валюта, Мальвіна, Фея, Norpro, Говерла. Коефіцієнт регресії тут знаходився в межах від 0,50 до 0,96. Серед середньостиглих стабільні зразки - Heinong $44\left(\mathrm{~b}_{\mathrm{i}=} 0,29\right)$, Селекта $201\left(b_{i=0}=45\right)$, Донька $\left(b_{i=1} 0,96\right)$.

Стабільним за коефіцієнтом регресії $\left(b_{i}\right) 3$ високою масою 1000 насінин виділено зразок Алмаз $\left(b_{i=} 0,96\right)$.
Маса 1000 насінин залежить від впливу погодних умов року, але значну роль у іiі вираженні мають властивості сорту. Мінливість маси 1000 насінин у ряді років може характеризувати біологічну пластичність сорту та адаптивність його до умов певного регіону. Чим менше змінюється цей показник, тим більше сорт підходить для даного регіону.

Розглянемо кількість та масу насіння з рослини у зразків, що перевищують сорти-стандарти за ознакою «маса 1000 насінин».

Однією із головних ознак в структурі рослини, яка обумовлює продуктивність сорту, $є$ маса насіння $з$ рослини. В середньому за три роки в ультраскоростиглій групі колекційні зразки формували таку масу насіння з рослини - OAC Vision 24,20 г, LF-8 - 22,33 г, Gaillard - 18,27 г, Злата 17,63 г.

3. Зразки колекції сої за масою насіння з рослини, г (середнє 2013-2015 рр.)

\begin{tabular}{|c|c|c|c|c|c|c|c|c|}
\hline $\begin{array}{l}\text { № } \\
\Pi / \Pi\end{array}$ & $\begin{array}{l}\text { Назва } \\
\text { зразка }\end{array}$ & $\begin{array}{c}\text { Номер } \\
\text { національно- } \\
\text { го каталогу }\end{array}$ & 2013 & 2014 & 2015 & $\bar{X} \pm s_{x}$ & $\mathrm{~V} \pm \mathrm{Sv}, \%$ & $b_{i}$ \\
\hline \multicolumn{9}{|c|}{ Ультраскоростиглі (менше 90-100 діб) } \\
\hline 1. & Аннушка-st & UD0201943 & 20,7 & 19,3 & 17,3 & $19,10 \pm 0,99$ & $8,95 \pm 3,65$ & 1,77 \\
\hline 2. & OAC Vision & UD0201929 & 24,7 & 24,1 & 23,8 & $24,20 \pm 0,26$ & $1,89 \pm 0,77$ & 0,35 \\
\hline 3. & LF-8 & UD0202379 & 23,1 & 22,3 & 21,6 & $22,33 \pm 0,43$ & $3,36 \pm 1,37$ & 0,69 \\
\hline 4. & Gaillard & UD0202360 & 17,5 & 18,1 & 19,2 & $18,27 \pm 0,50$ & 93 & $-0,93$ \\
\hline 5. & Злата & UD0202426 & 18,7 & 17,9 & 16,3 & $17,63 \pm 0,71$ & 6,93 & 1,34 \\
\hline \multicolumn{9}{|c|}{ Скоростиглі (101-120 діб) } \\
\hline 1. & $\begin{array}{c}\text { Васильківська- } \\
\text { st }\end{array}$ & UD0202340 & 22,6 & 23,1 & 21,8 & $22,50 \pm 0,38$ & $2,91 \pm 1,19$ & $\mathbf{0 , 8 3}$ \\
\hline 2. & Алмаз & UD0202309 & 31,2 & 30,3 & 27,8 & $29,77 \pm 1,02$ & $5,92 \pm 2,42$ & 2,02 \\
\hline 3. & Устя & UD0200773 & 23,5 & 24,9 & 25,1 & $24,50 \pm 0,50$ & $3,56 \pm 1,45$ & $-0,46$ \\
\hline 4. & КиВін & UD0201952 & 30,2 & 28,6 & 27,9 & $28,90 \pm 0,68$ & $4,08 \pm 1,67$ & 0,87 \\
\hline 5. & & UD0202628 & 25,2 & 26,3 & 24,1 & $25,20 \pm 0,64$ & $4,37 \pm 1,78$ & 1,35 \\
\hline 6. & Віль & UD0202562 & 23,2 & 26,1 & 19,8 & & $13,69 \pm 5,59$ & 3,93 \\
\hline 7. & & UD0201974 & 21,4 & 25,2 & 27,3 & 24,63 & 4,96 & $-2,38$ \\
\hline 8. & Юг-40 & UD0200203 & 24,5 & 26,2 & 20,1 & $23,60 \pm 1,82$ & $13,34 \pm 5,45$ & 4,05 \\
\hline 9. & Фортуна & UD0202308 & 23,1 & 25,5 & 21,6 & $23,40 \pm 1,14$ & $8,41 \pm 3,43$ & 2,30 \\
\hline 10. & Поема & UD0202304 & 24,1 & 25,7 & 23,8 & $24,53 \pm 0,59$ & $4,16 \pm 1,70$ & 1,02 \\
\hline 11. & Хвиля & UD0202466 & 30,8 & 28,4 & 26,5 & $28,57 \pm 1,24$ & $7,54 \pm 3,08$ & 1,92 \\
\hline 12. & Артеміда & UD0200978 & 22,1 & 24,4 & 20,6 & $22,37 \pm 1,11$ & $8,56 \pm 3,49$ & 2,25 \\
\hline \multicolumn{9}{|c|}{ Середньостиглі (121-140 діб) } \\
\hline 1. & $\begin{array}{l}\text { Чернівецька-8- } \\
\text { st }\end{array}$ & UD0200285 & 21,7 & 25,1 & 27,4 & $24,73 \pm 1,66$ & $11,59 \pm 4,73$ & $-2,43$ \\
\hline 2. & & UD0200615 & 32,4 & 27,6 & 23,5 & $27,83 \pm 2,57$ & $16,00 \pm 6,53$ & 4,05 \\
\hline 3. & Маша & UD0201933 & 28,1 & 29,4 & 26,2 & $27,90 \pm 0,93$ & $5,77 \pm 2,35$ & 2,04 \\
\hline 4. & Фарватер & UD0202311 & 30,1 & 33,5 & 27,4 & $30,33 \pm 1,76$ & $10,08 \pm 4,11$ & 3,67 \\
\hline 5. & Славія & UD0202451 & 24,8 & 26,1 & 22,1 & $24,33 \pm 1,18$ & $8,39 \pm 3,42$ & 2,62 \\
\hline 6. & Ельдорадо & UD0202315 & 28,4 & 31,2 & 26,9 & $28,83 \pm 1,26$ & $7,57 \pm 3,09$ & 2,50 \\
\hline 7. & Іванка & UD0200238 & 26,4 & 28,3 & 22,9 & $25,87 \pm 1,58$ & $10,59 \pm 4,32$ & 3,50 \\
\hline
\end{tabular}


СІЛЬСЬКЕ ГОСПОДАРСТВО. РОСЛИННИЦТВО

4. Зразки колекції сої за кількістю насіння з рослини, шт. (середне 2013-2015 рр.)

\begin{tabular}{|c|c|c|c|c|c|c|c|c|}
\hline $\begin{array}{l}\text { № } \\
\text { П/ா }\end{array}$ & $\begin{array}{l}\text { Назва } \\
\text { зразка }\end{array}$ & $\begin{array}{c}\text { Номер } \\
\text { національно- } \\
\text { го каталогу }\end{array}$ & 2013 & 2014 & 2015 & $\bar{X} \pm s_{x}$ & $\mathrm{~V} \pm \mathrm{Sv}, \%$ & $b_{i}$ \\
\hline \multicolumn{9}{|c|}{ Ультраскоростиглі (менше 90-100 діб) } \\
\hline 1. & Аннушка-st & UD0201943 & 126,2 & 120,4 & 116,2 & $120,93 \pm 2,90$ & $4,15 \pm 1,70$ & 1,28 \\
\hline 2. & OAC Vision & UD0201929 & 130,3 & 122,1 & 129,5 & $127,30 \pm 2,61$ & $3,55 \pm 1,45$ & $-1,08$ \\
\hline 3. & LF-8 & UD0202379 & 115,3 & 121,3 & 108,4 & $115,00 \pm 3,73$ & $5,61 \pm 2,29$ & 2,41 \\
\hline 4. & Gaillard & UD0202360 & 109,5 & 107,4 & 118,5 & $111,80 \pm 3,40$ & $5,27 \pm 2,15$ & $-2,27$ \\
\hline 5. & Злата & UD0202426 & 105,5 & 107,9 & 100,5 & $104,63 \pm 2,18$ & $3,61 \pm 1,47$ & 1,45 \\
\hline \multicolumn{9}{|c|}{ Скоростиглі (101-120 діб) } \\
\hline 1. & Васильківська-st & UD0202340 & 115,1 & 119,6 & 110,1 & $114,93 \pm 2,74$ & $4,13 \pm 1,69$ & 1,77 \\
\hline 2. & Алмаз & UD0202309 & 145,9 & 137,4 & 125,8 & $136,37 \pm 5,83$ & $7,40 \pm 3,02$ & 3,05 \\
\hline 3. & Устя & UD0200773 & 121,4 & 118,3 & 125,6 & $121,77 \pm 2,12$ & $3,01 \pm 1,23$ & $-1,38$ \\
\hline 4. & КиВін & UD0201952 & 182,4 & 175,6 & 173,1 & $177,03 \pm 2,78$ & 2,72 & 0,97 \\
\hline 5. & Адамос & UD0202628 & 127,2 & 129,3 & 120,5 & $125,67 \pm 2,65$ & $3,66 \pm 1$ & 1,77 \\
\hline 6. & Вільшанка & UD0202562 & 118,9 & 125,4 & 112,3 & $118,87 \pm 3,78$ & $5,51 \pm 2,25$ & 2,42 \\
\hline 7. & Мрія & UD0201974 & 110,2 & 118,9 & 125,4 & $118,17 \pm 4,40$ & $6,45 \pm 2,63$ & $-1,96$ \\
\hline 8. & Юг-40 & UD0200203 & 113,4 & 115,2 & 106,5 & $111,70 \pm 2,65$ & $4,11 \pm 1,68$ & 1,77 \\
\hline 9. & Фортуна & UD0202308 & 121,3 & 125,4 & 110,4 & $119,03 \pm 4,48$ & $6,51 \pm 2,66$ & 2,99 \\
\hline 10. & Поема & UD0202304 & 118,3 & 115,3 & 109,5 & $114,37 \pm 2,58$ & $3,91 \pm 1,60$ & 1,45 \\
\hline 11. & Хвиля & UD0202466 & 151,8 & 140,2 & 133,7 & $141,90 \pm 5,29$ & $6,46 \pm 2,64$ & 2,14 \\
\hline 12. & Артеміда & UD0200978 & 118,6 & 110,1 & 106,5 & $111,73 \pm 3,59$ & $5,56 \pm 2,27$ & 1,32 \\
\hline \multicolumn{9}{|c|}{ Середньостиглі (121-140 діб) } \\
\hline 1. & Чернівецька-8-st & UD0200285 & 99,6 & 110,1 & 114,5 & $108,07 \pm 4,42$ & $7,08 \pm 2,89$ & $-1,62$ \\
\hline 2. & Подолянка & UD0200615 & 128,2 & 123,1 & 117,5 & $122,93 \pm 3,09$ & $4,35 \pm 1,78$ & 1,54 \\
\hline 3. & Маша & UD0201933 & 129,3 & 132,4 & 115,6 & $125,77 \pm 5,16$ & $7,11 \pm 2,90$ & 3,44 \\
\hline 4. & Фарватер & UD0202311 & 130,2 & 137,4 & 125,6 & $131,07 \pm 3,43$ & $4,54 \pm 1,85$ & 2,10 \\
\hline 5. & Славія & UD0202451 & 118,2 & 127,4 & 114,7 & $120,10 \pm 3,79$ & $5,46 \pm 2,23$ & 2,17 \\
\hline 6. & Ельдорадо & UD0202315 & 128,5 & 135,7 & 121,4 & $128,53 \pm 4,13$ & $5,56 \pm 2,27$ & 2,64 \\
\hline 7. & Іванка & UD0200238 & 122,6 & 126,9 & 109,5 & $119,67 \pm 5,23$ & $7,57 \pm 3,09$ & 3,49 \\
\hline
\end{tabular}

В скоростиглій - Алмаз 29,77 г, Устя - 24,50 г, Кивін - 28,90 г, Адамос - 25,20 г, Вільшанка 23,03 г, Мрія - 24,63 г, Юг-40 - 23,60 г, Фортуна - 23,40 г, Поема - 24,53 г, Хвиля - 28,57 г, Артеміда - 22,37 г. У середньостиглій групі стиглості - Подолянка - 27,83 г, Маша - 27,90 г, Фарватер - 30,33 г, Славія - 24,33 г, Ельдорадо 28,83 г, Іванка $-25,87$ г (табл. 3).

Більшість зразків за ознакою маса насіння 3 рослини слабомінливі. Сортозразки також різнилися за параметрами пластичності і стабільності. Серед ультраскоростиглих зразків стабільними ( $\mathrm{b}_{\mathrm{i}}$ від 0 до 1) виявлено - Легенда, OAC Vision, Танаїс, LF-8, коефіцієнт регресії $\left(b_{i}\right)$ знаходився в межах від 0,35 до 0,93. Серед скоростиглих стабільними були Васильківська, Лика, Єлена, AC Bravor, Сузір'я, Фаетон, ВНИИОЗ-76, Nattawa, Хуторяночка, Валюта, Естафета, Кивін, Мальвіна, Київська-27, Фея, Л-101, Харківська80, Спринт, Срібна Рута, Говерла. У даних зраз- ків коефіцієнт регресії $\left(\mathrm{b}_{\mathrm{i}}\right)$ знаходився в межах від 0,03 до 0,99. Серед середньостиглих стабільні зразки - Селекта $201 \quad\left(\mathrm{~b}_{\mathrm{i}=0,93)}\right.$ i Sacura

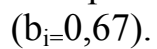

Стабільними за коефіцієнтом регресії $\left(\mathrm{b}_{\mathrm{i}}\right)$ з високою масою насіння 3 рослини виділені зразки Кивін $\left(b_{\mathrm{i}}=0,87\right)$, OAC Vision $\left(b_{\mathrm{i}}=0,35\right)$, LF-8

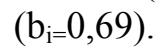

Основна маса зразків за ознакою кількість насіння $з$ рослини слабомінливі. Більшість ультраскоростиглих зразків показали себе як інтенсивні $\left(b_{i}>1\right)$, тобто при покращенні умов вирощування давали кращий результат. Лише зразки ОАС Vision, Золотиста, Gaillard і Кобза відзначились високими відємними коефіцієнтами пластичності, що вказує на тенденцію давати кращий результат при гірших умовах вирощування. Серед скоростиглих стабільними виявились зразки: Київська-27, Ніна, Фея, Optimus, Norpro, Говерла, Валюта, Естафета, Кивін, Ствига. У даних 
зразків коефіцієнт регресії $\left(\mathrm{b}_{\mathrm{i}}\right)$ знаходився в межах від 0,04 до 0,98. Серед середньостиглих ста-

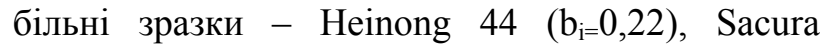

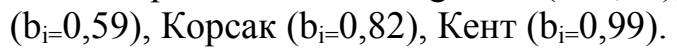

Стабільним за коефіцієнтом регресії $\left(b_{i}\right)$ з високою кількістю насіння з рослини виділено зра-

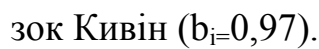

Висновки. Оцінка селекційного матеріалу за комплексом господарськи цінних ознак має важливе значення при створенні нових високопродуктивних сортів 3 адаптивним потенціалом. В результаті проведеного дослідження за такими важливими ознаками, як маса 1000 насінин, кількість насіння з рослини, маса насіння 3 росли-

\section{БІБЛІОГРАФІЯ}

1. Бабич А. О., Бабич-Побережна А. А. Селекція і виробництво сої в Україні. - Вінниця, 2008. $-215 \mathrm{c}$.

2. Бабич А. О. Сучасне виробництво і використання сої. - К. : Урожай, 1993. - 429 с.

3. Білявська Л. Г. Аспекти адаптивної селекції сої в умовах зміни клімату. - Корми і кормовиробництво, 2008. - №61. - С. 10-16.

4. Боровик В. О., Кузьмич В. І., Клубук В. В., Рубиов Д. К., Головаш Л. М. Характеристика нових зразків сої за морфо-біологічними та господарськими ознаками. - Зрошуване землеробство, 2017. - Випуск 67. - С. 122-126.

5. Гуреева Е. В., Фомина T. А. Оценка коллекционных образцов сои как исходного материала для селекции. - Зернобобовые и крупяные культуры, 2016. - №1 (17). - С. 40-45.

6. Доспехов Б. А. Методика полевого опыта (с основами статистической обработки результатов исследований). - М. : Агропромиздат, 1985. $351 \mathrm{c}$.

7. Кобизєва Л. Н. Різноманіття колекційного матеріалу гороху, сої, квасолі, нуту та сочевиці за рівнем біологічної урожайності. - Селекція і насінництво, 2014. - Випуск 106. - С. 34-41.

8. Коханюк Н. В. Оцінка зразків сої на основі кореляції кількісних ознак та індексів. - Селекція і насінництво, 2014. - Випуск 106. - С. 7176.

9. Лавриненко Ю. О., Кузьмич В.І., Боровик $B$. O. Селекція сої на покращення ознак продуктивності та якості в умовах зрошення. - Зрошуване землеробство, 2016. - Випуск 66. - С. 113115. ни виділено цінні зразки OAC Vision, LF-8, Gaillard, Злата, Алмаз, Устя, Кивін, Адамос, Вільшанка, Мрія, Юг-40, Фортуна, Поема, Хвиля, Подолянка, Маша, Фарватер, Славія, Ельдорадо, Іванка, які доцільно використовувати для подальшої селекційної роботи.

Стабільним за коефіцієнтом регресії $\left(\mathrm{b}_{\mathrm{i}}\right)$ з високою масою 1000 насінин виділено зразок Ал-

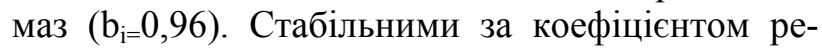
гресії $\left(\mathrm{b}_{\mathrm{i}}\right)$ з високою масою насіння 3 рослини

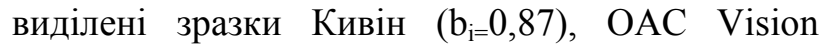

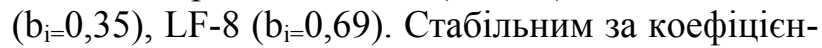
том регресії $\left(b_{i}\right)$ з високою кількістю насіння 3

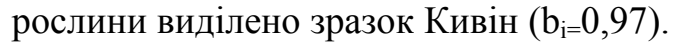

10. Соя (генетика, селекция, семеноводство). А. К. Лещенко, В. И. Сичкарь, В. Г. Михайлов [и др.]. - К. : Наукова думка, 1987. - 255 с.

11. Марченко Т. Ю. Прояв гетерозису за ознакою «маса 1000 насінин» у гібридів сої в умовах зрошення півдня України. -Таврійський науковий вісник. - Вип. 80, 2012. - С. 114-118.

12. Мєдвєдєва Л. Р., Холковська О. О. Результати і перспективи селекції сої у Кіровоградському АПВ. - Зб. наук. праць СГІ-НЦНС, 2010. Вип. 15 (55). -С. 94-100.

13. Методические указания по изучению коллекции зерновых бобовых культур. Н. И. Корсаков, О. А. Адамова [и др.]. - Л., 1975. - 59 с.

14. Павленко Г. В. Вплив елементів технології вирощування на формування структури та урожайності сої в умовах північної частини Лісостепу. [Електронний ресурс]. Наукові доповіді НУБіП України, 2015. - №4 (53). - URL : http://journals.uran.ua/index.php/2223-

1609/article/view/116476/110501.

15. Петриченко В. Ф., Іванюк С. В. Вплив сортових і гідротермічних ресурсів на формування продуктивності сої в умовах Лісостепу. - Зб. наук. праць Інституту землеробства УААН, 2000. Вип. 3-4. - С. 19-24.

16. Січкар B. I. Селекційна цінність колекційних зразків при створенні високопродуктивних сортів сої. - Селекція і насінництво, 2014. Випуск 106. - С. 83-92.

17. Широкий уніфікований класифікатор роду Glycine max. (L). Merr. Л. Н. Кобизєва, В. К. Рябчун, О. М. Безугла [та ін.]. УААН, Ін-т рослинництва ім. В. Я. Юр'єва. - Харків, 2004. $37 \mathrm{c}$. 


\section{ANNOTATION}

Biliavs'ka L. G., Rybal'chenko A. M. Formation of seed profitability in collective samples of soybean in the conditions of Ukraine's Forest-Steppe.

The article presents the results of research on the formation of seed productivity of soybean collection samples for 2013-2015. Evaluation of breeding material in a complex of economic and valuable features is important for the creation of new highyield varieties with adaptive potential. The valuable samples for further breeding work have been selected for such important features as the mass of 1000 seeds and the amount of seed from the plant and the mass of seed from the plant, respectively. It was found that among the specimens of the ultrafast-growing group on the basis of the mass of 1000 seeds, the samples such as OAS Vision (167.33 g), LF-8 (155.00 g), Gaillard (162.33 g), Zlata ( 150.00 g). In the fast-growing group, such varieties as Diamond (183.67 g), Ustia (179.33 g), Kivin (184.67 g), Adamos (164.67 g), Vlishanka (165.00 g), Mriya (168.00 g), South-40 (165.67 g), Fortun $(168.00 \mathrm{~g})$, Poem $(171.00 \mathrm{~g})$, Hvylia $(173.00 \mathrm{~g})$, Artemis $(165.00 \mathrm{~g})$ were better than the varietystandart Vasyl'kivska. The best-in-class than standard Chernivtsi-8 in the middle-eastern group of maturity was Podolianka (178.33 g), Masha (176.67 g), Farwater (176.33 g), Slavia (176.00 g), Eldorado $(179.33 \mathrm{~g})$, Ivanka (175.33 g). The sample Diamond (bi $=0,96$ ) is steady with a coefficient of regression (bi) with a high weight of 1000 seeds.

One of the main signs in the structure of the plant, which determines the productivity of the variety, is the mass of seeds from the plant. On average, over three years in the ultra-fast-growing group, the collection samples formed a mass of seed from the plant - OAS Vision - 24.20 g, LF-8 - 22.33 g, Gaillard $-18.27 \mathrm{~g}$, Zlata $-17.63 \mathrm{~g}$. In the strain Diamond 29.77 g, Ustia - 24.50 g, Kivin -28.90 g, Adamos - 25.20 g, Vlishanka - 23.03 g, Dream 24.63 g, South-40 - 23.60 g, Fortune -23.40 g,
Poem - 24,53 g, Hvylia - 28,57 g, Artemis - 22,37 g. In the middle-eastern group of ripeness Podolianka - 27.83 g, Masha - 27.90 g, Farwater 30.33 g, Slavia - 24.33 g, Eldorado - 28.83 g, Ivanka $-25.87 \mathrm{~g}$. Regular bias stable (bi) with high weight of seed from the plant you Distributed Kivin samples $(\mathrm{bi}=0.87), \mathrm{OAC}$ Vision $(\mathrm{bi}=0.35), \mathrm{LF}-8$ (bi=0.69).

The average number of seeds from the plant in the collection varieties of soybeans varied in 2013 from 58.1 to 182.4 pcs., in 2014 - from 68.5 to 175.6 pp., in 2015 - from 54.6 to 173,1 pcs. On average over three years in the ultra-fast-growing group, the collection samples formed the amount of seed from the plant - OAS Vision - 127.30 pcs., LF-8 - 115.00 pcs., Gaillard - 111.80 pcs., Zlata 104.63 pcs. In the fast-cutting - Diamond 136.37 units, Ustia - 121.77 units, Kivin - 177.03 units, Adamos - 125.67 units, Vil'shanka - 118.87 units, Mriya - 118.17 units, South-40 - 111.70 pieces, Fortuna -119.03 units, Poem - 114.37 units, Hvylia - 141.90 units, Artemis - 111.73 units. In the middle age group of ripeness - Podolianka - 122.93 units, Masha - 125.77 units, Farwater - 131.07 units, Slavia - 120.10 units, Eldorado - 128.53 units, Ivanka - 119.67 pcs. A sample of Kivin $(\mathrm{bi}=0,97)$ is steady under the coefficient of regression (bi) with high amount of plant seeds.

As a result of the research conducted on such important features as the mass of 1000 seeds, the amount of seed from the plant, the weight of the seeds from the plant highlighted valuable samples OAS Vision, LF-8, Gaillard, Zlata, Diamond, Ustia, Kivin, Adamos, Vil'shanka, Mriya, South-40, Fortune, Poem, Hvylia, Podolianka, Masha, Farwater, Slavia, Eldorado, Ivanka, which are expedient to use for further breeding work.

Key words: soybean, sample, collection material, weight of 1000 seeds, seed productivity. 